\title{
The Effect of Activity-Based Costing (ABC) on Managing the Efficiency of Performance in Jordanian Manufacturing Corporations - An Analytical Study
}

\author{
Dr. Nabil Bashir Al-Halabi ${ }^{1} \&$ Dr. Omar Fareed Shaqqour ${ }^{1}$ \\ ${ }^{1}$ Accounting Department, Faculty of Economics and Administration, Sciences, Zarqa University, Jordan. P.O. Box \\ 132222, Zarqa 13110, Jordan \\ Correspondence: Prof. Nabil Bashir Al-Halabi, Accounting Department, Zarqa University, Jordan. P.O. Box 132222, \\ Zarqa 13110, Jordan. E-mail: alhalabi.fcs@ gmail.com or nhalabi@ zu.edu.jo
}

Received: September 6, 2017

Accepted: September 25, 2017

Online Published: February 1, 2018

doi:10.5430/afr.v7n1p262

URL: https://doi.org/10.5430/afr.v7n1p262

\begin{abstract}
The study explored the effect of activity-based costing (ABC) on the efficiency of performance in Jordanian manufacturing corporations. A questionnaire form was designed and distributed to a sample of 72 managers in 20 manufacturing corporations, and data were collected and analyzed using EXCEL and SPSS packages. The results found that the application of $\mathrm{ABC}$ has a significant effect on managing resources, performance efficiency, cost reduction, and costs of unused capacity in Jordanian manufacturing corporations. The conclusion showed that $\mathrm{ABC}$ were able to differentiate between high and low volume products among different activities of manufacturing corporation in Jordan. The research also concluded that the main difficulties were in differentiating between value added and non value added activities, unclear strategies, and incomplete information for decision making processes, thus, whatever activity-slack existed more levels of cooperation also existed between members of the value chain (VC). The study recommended more application of the $\mathrm{ABC}$ in different corporations as proved its effect on pricing decisions, cost reduction and a competitive ability of corporations in different markets.
\end{abstract}

Keyword: Activity based costing, Performance, Manufacturing corporations

\section{Introduction}

The current century has witnessed many technological changes, globalization, open international markets, product diversification and more comparative competition in a move towards modern manufacturing environments that required new approaches to solve problems facing management to use available resources efficiently and conduct predetermined goals (Judeh, et al., 2011, p. 20). In addition, there are many factors causing difficulties facing businesses, such the absence of ineffective tools for performance evaluation that caused businesses' failure or success (Whittington and Delany, 2013, P. 77). Terminologies, such as, cost efficiency, functional and dysfunctional behaviors, accurate overhead cost assignments usually used in businesses, and the use different techniques to reduce costs and increase the wealth of shareholders (Al-Halabi, 2013, p.4; Krishnan, 2006, p. 6). It is pointed out that the improvement of current cost systems, cost classifications can lead to stability of internal operations of businesses (King, 2001, p.27). Similarly, managers at different levels could used modern technology and cost tools to take sound economic decisions and to tackle problems of inefficiency and ineffectiveness in all activities of business (Dutta, and Gigler, 2002, p. 15).

Recently, many studies applied modern cost assignment tools and techniques in businesses that can affect performance and reduce costs aiming at maximizing wealth of shareholders (Chi, Listic and Pevzner, 2011, p 319; Dorgham, Al-Halabi and Shanikat, 2014, p. 4; Greiner, Kohlbeck and Smith, 2013, p. 12). Another studies talked about control and its tools to help accounting and management control by improving current performance measures and audit reports for owners of corporations (Rapp, 2010; Al-Halabi, 2016, p.55; Hilton, 2008, p. 231). In the cost accounting context, there were many attempts to overcome decreases in performance of activities which enhanced discussion on corporations' size and nature of business, and the role of management in finding out possible solutions for such weak performance gaps (Hopwood, 1977). Moreover, managers usually use the available performance evaluation tools with no efforts to develop these tools in accordance with changing circumstances, leading to dysfunctional performance results (Al-Halabi, 2016, p. 57).

Furthermore, the application of $\mathrm{ABC}$ make business pricing decisions more easy to change for different products and, 
accordingly, the management is challenged to find out alternative approaches to improve performance methods, reduce costs, and to face new competitive developments, ending with maximizing the wealth of corporations' shareholders (Rapp, Marc Steffen, 2010, p. 5). Similarly, other studies indicated that corporations are interested to decrease costs through linking the use of $\mathrm{ABC}$ with the target costing in corporations (Hilton, R., 2008, p. 234).

This study contain of four parts, the study literature, the study methodology, the study results, the study conclusions and recommendations about the effect of applying the $\mathrm{ABC}$ performance efficiency in Jordanian manufacturing corporations.

\section{Study Literature}

The literature disclosed a set of alternatives to develop traditional cost approaches, thus, the $A B C$ which resulting in accurate assignment of indirect costs on activities and relying on quantitative and qualitative criteria to support pricing decisions (Drury, 2006, p.9; Ellis,2003, p.334; Brimson, 2001, p.182 ). In fact, an activity-based costing system or approach relied on a three-phase approach starting with identification of main and support activities that added values to the corporation, followed by identifying quantitative and qualitative cost drivers used for indirect costs allocation, thus, accumulating costs into cost pools or activities' cost centers, and ending up with the allocation of activities costs to cost objects (Garrison and Noreen, 2006, p.95; Steimer, 2000, p.42;).

It is said that the adoption of the $\mathrm{ABC}$ system can overcome several problems related to the use of the traditional system particularly for those problems associated with the volume-based activity, types of cost drivers, and the path of value chain within activities in corporations (Drury, 2004, p.109; Kaplan and Atkinson, 1997, p.222; Shimizu, 2013 p. 28; Khan, 2011, p.178; Reynolds, \& Poll, 2015, p. 9). Actually, integrating the ABC with the Kaizon approach proved to have cost reduction through the comparison being made between the initial cost and the target cost, increasing profitability and achieving competitive advantages (Shimizu, 2013 p. 30; Garrison and Noreen, 2002, p.145; Adams et. al., 2010, p. 313). Some researchers went further to indicate the interaction between prices and costs that can be seen important in order to achieve predetermined objectives (Shiozawa, 2006, p.29). Among such inside and outside environments, traditional costing techniques were unable to stand in competitive markets particularly with the percentage of overhead costs exceeded 55\% of the total cost hierarchy (Gorzen-Mitka \& Okreglicka, 2014, p. 231). Furthermore, the decisions of pricing be easy to change on different product, and obliged management to know the suitable approaches that consistant with new developments of competitive to increase performance and profit (Rapp, Marc Steffen, 2010, p. 5).

A modern cost structure seen as consisted of direct materials and overhead costs with the replacement of direct wages to be embodied into overheads in most manufacturing corporations, and thus the cost structures have the triple-dimensions effect represented by: cost, performance and quality (CPQ) (Swenson \& Ansar, 2010, p. 11; Negulescu, \& Doval, 2014, p. 62). Therefore, assigning costs to activities instead of centers is crucial for management since overhead burdens included most of direct labor costs and can affect the total cost hierarchy for many products being produced by medium and large corporations (Rozotocki, 2010. P. 7). As a result one way facing the management is to adopt accurate cost assignment tools such as the activity based costing (ABS) that leads to better performance, maintaining quality of its products, accurate cost assignments to activities charts and then to cost objects, leading to sound pricing decisions (Moorthy \& Yacob, , (2013, p. 5).

Although the interaction between the ABC and both target costing (TC) and Kaizon approaches is important, many studies referred to the necessity of such interaction between the $\mathrm{ABC}$ and both the activity based management (ABM), and the value chain (VC) which consisted of many phases: starting with the design of new services or improving current services; passing through raw material suppliers, maintenance of suppliers; and ending up with customers through distributors and agents, and other parties who may get benefits from the members participation of the VC (Khan, 2011, p.181; Shimizu, 2013 p. 30). On the other hand, some studies focused on the value chain application and analysis to achieve effective linkage between different phases of the VC and creating conditions to increase clients' satisfaction, reduction of costs, and improving the quality of operations (Gleim and Flesher, 2014, p.160; Adams et al., 2010, p. 313). Analyzing resources within main and support activities using modern cost tools can help in identifying unused capacity by applying the following formula found earlier (Cooper and Kaplan, 1992):

Resources Supplied Cost $=$ Resources Used Cost + Unused Capacity Cost

Based on the aforementioned formula managers and top management can use the $\mathrm{ABC}$ to identify the cost of resources used in corporations, and to compare this result with the total cost of resources supplied to an activity, so managers can identify the cost of unused capacity to exert control and work procedures to overcome cost of unused capacity (Gill, \& Obradovich, 2012, p. 11). This can not be achieved without an integration between the ABC and the ABM and in 
particular for those activities that have both quantitative and qualitative cost drivers. Thus, the cooperation principle is needed between members of activities' chart and related parties within the corporation, such as production, purchasing, warehousing, accounting and finance, and marketing and selling members (Horngren, et al., 2006, p. 143; Gleim and Flesher, 2014, p.163). For those who are outside the corporation whether they are dealing directly with the corporation or benefitting from its services (such as: reliable creditors, customers, governmental parties, environmentalists, and tax authorities) they must be initiated and linked (Camacho and Rocha 2008, p.26). Other researchers went further and discussed strategies adopted by competitors of corporations to which the cooperation between members of the value chain is urgently needed to support the competitive advantage through the price distinction that fulfilled the corporation's strategy (Khan, 2011, p.183; Schinckus, 2010, 128; Gibson, 2015, p 280).

Based on the aforementioned discussion this study aims to identify the effect of applying $\mathrm{ABC}$ on the efficiency of performance in Jordanian manufacturing corporations.

\section{Study Methodology}

The study methodology adopted analytical and descriptive approach, where the data extracted from the research toolthe questionnaire form- were studied and analyzed towards achieving the study's goals. Thus, the study methodology presented the study problem, study hypotheses, study methods, study limitations, and the study's operating definitions.

\subsection{The Study Problem}

Many manufacturing corporations apply the current traditional costing systems in isolation of other modern cost approaches and they keep applying these systems without realizing the importance of integration between modern cost tools. The application of traditional costing systems led for multi-products corporations to inefficient allocation of resources, cost distortion, and difficulties in providing relevant information for economic and pricing decisions ending up with the instability in the economy. The application of $\mathrm{ABC}$ as a modern system for cost that support in achieving the integration with the activity based management (ABM) necessary for Jordanian corporations to enable them in enhancing their market place and secure continuity in the Jordanian economy.

The study problem is knowing by these questions:

1. Is there an effect of applying the $\mathrm{ABC}$ on managing resources in activities of Jordanian manufacturing corporations?

1.1 Is there an effect of applying the $\mathrm{ABC}$ on identifying cost of resources used in activities of Jordanian manufacturing corporations?

1.2 Is there an effect of applying the $\mathrm{ABC}$ on identifying cost of unused capacity in activities of Jordanian manufacturing corporations?

2. Is there an effect of applying the $\mathrm{ABC}$ on efficiency of performance of Jordanian manufacturing corporations?

2.1 Is there an effect of applying the $\mathrm{ABC}$ on decreasing cost of products in activities of Jordanian manufacturing corporations?

3. Are there significant differences on the effect of applying ABC on managing the resources and efficiency of performance in Jordanian manufacturing corporations attributed to management participation?

The Study focused on identify the effect of applying the ABC on managing resources and efficiency of performance of Jordanian manufacturing corporations, as figure 1 shown. 


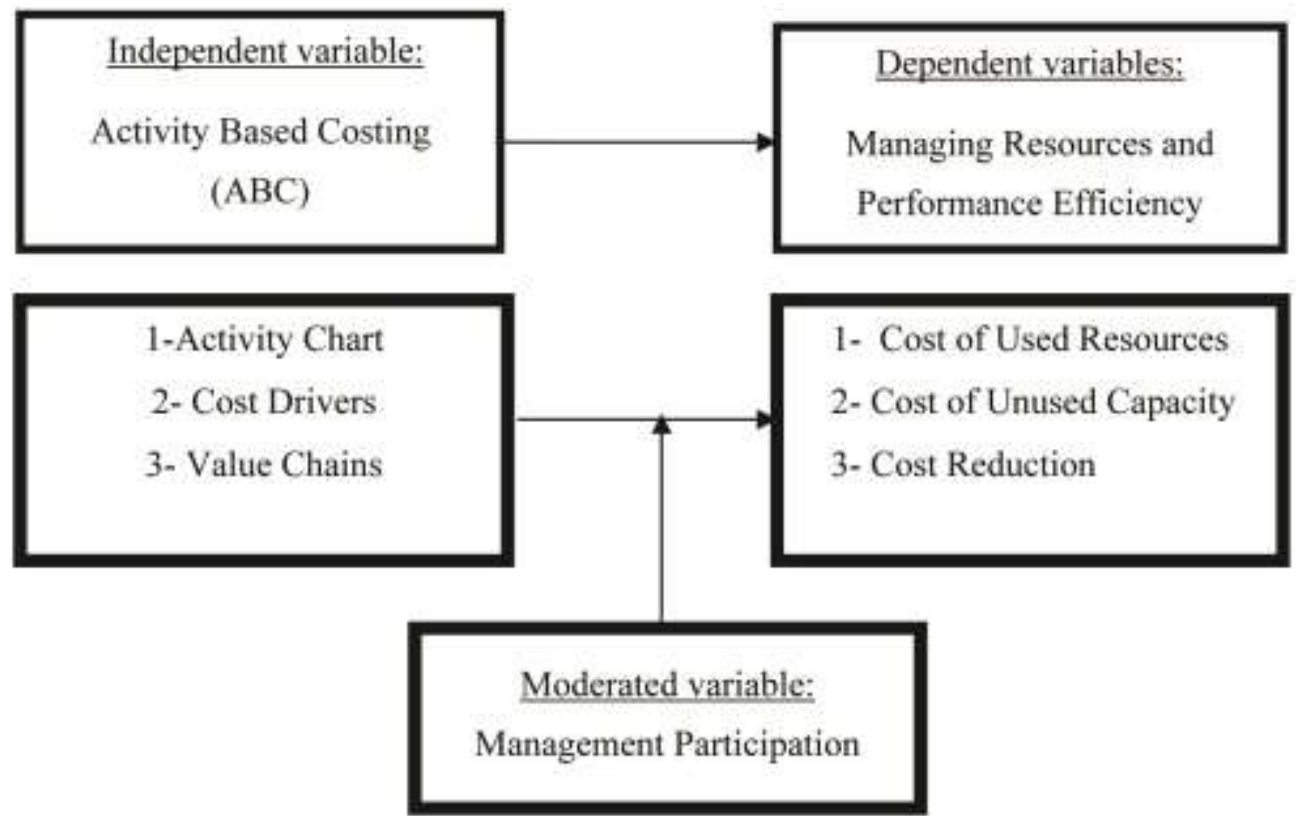

Figure 1.

Source: Designed by researchers based on (Drury, 2006,; Garrison, Noreen, \& Brewer, 2006, P. 87; and Cooper and Kaplan, 1992).

\subsection{Study Hypotheses}

The Study hypotheses are:

H01 There is no significant effect of applying ABC on managing resources of Jordanian manufacturing corporation.

H01-1 There is no significant effect of applying the $\mathrm{ABC}$ on identifying the cost of resources used in activities of Jordanian manufacturing corporations.

H01-2 There is no significant effect of applying the $A B C$ on identifying the cost of unused capacity in activities of Jordanian manufacturing corporations.

H02 There is no significant effect of applying the ABC on the performance efficiency in activities of Jordanian manufacturing corporations.

H02-1 There is no significant effect of applying the $\mathrm{ABC}$ on reducing the cost of products in activities of Jordanian manufacturing corporations.

H03 There are no significant differences on the effect of applying ABC on managing resources and efficiency of performance in Jordanian manufacturing corporations attributed to management participation.

\subsection{Study Method}

The study designed and distributed a questionnaire form to a sample of 72 managers, at different levels, in 20 manufacturing corporations listed on Amman Stock Exchange (ASE) in 2016, selected randomly, and the data collected were analyzed using EXCEL and SPSS packages. Accordingly, 72 questionnaires forms out of 80 questionnaires forms were distributed to top and middle levels: 12 participants from the top level; 22 participants from the middle level; and 38 participants representing auditors and accountants at the finance and control activities, as shown in schedule 1 . 
Schedule 1. Study sample distribution and the response percentage

\begin{tabular}{lcccc}
\hline Distribution & $\begin{array}{c}\text { Middle } \\
\text { Managers }\end{array}$ & $\begin{array}{c}\text { Top } \\
\text { and }\end{array}$ & $\begin{array}{c}\text { Management } \\
\text { Owners }\end{array}$ & Total \\
\hline 1- CEO, BOD members and owners & -- & 15 & 15 \\
$\begin{array}{l}\text { 2- Financing, controlling planning, selling, and } \\
\text { purchasing. }\end{array}$ & 25 & -- & 25 \\
3- Accountants and Auditors & 40 & -- & 40 \\
Total & 65 & 15 & 80 \\
response number & 60 & 12 & 72 \\
response percentage & $92 \%$ & $80 \%$ & $90 \%$ \\
\hline
\end{tabular}

\subsection{Limitations of Study}

The researchers found difficulties in collecting data, they are:

1- More efforts were required to follow participants to complete the questionnaires, and ensure that the questionnaire forms was completeness.

2- Some persons needed more explanations before completing the questionnaire and others were not located in the right position.

3- It was difficult to match the job description with the participant knowledge and experience.

\subsection{Operational Definitions}

1- ABC: it is a modern approach for cost apply by corporations that have many products to produce. The ABC uses different quantitative and qualitative cost drivers and differentiated between high and low-volume products taking into account the economies of scale. The $\mathrm{ABC}$ system can have positive effects on each individual product for competition purposes and it is able to accommodate modern manufacturing environments (Brimson, 2001, p. 78; King, 2001, p.26).

2- Activity Chart: there are different activities that uses resources, of materials, and plays a role in adding value to the corporation, thus, the activity chart is a list of activities within the corporation (Garrison, R., Noreen, 2006, p. 68).

3- Cost Drivers: They represented two types, quantitative, such as direct labor hours, and qualitative, such as times of setting up machines (Brimson, 2001, p. 79).

4- Value Chains: a value chain (VC) consisted of many phases: starting with the design of new products, raw material supplies and reliable suppliers, and ending up with the selling process to customers and other parties where the value chain application helps in coordinating each parts of the chain and finding a conditions to increase customer satisfaction, cost efficiency, and product quality (Shimizu, 2013 p. 30; Adams et al., 2010, p. 313).

5- Managing Resources: it is important for management to adopt criteria such as establishing different activities or an activity chart with aim of achieving full benefits from the application of ABC. Actually, effective managing resources is reached through the interaction between the $\mathrm{AMB}$ and $\mathrm{ABC}$ in each step of the value chain across main and support activities (Greenwood \& James, 2002, p 33).

6- Performance Efficiency: it represented how efficient the management can apply performance measures, such as BSC whether for persons or for the corporation, to achieve goals and sub goals in corporations and the ability to link the application of $\mathrm{ABC}$ and $\mathrm{ABM}$, where the $\mathrm{ABC}$ can lead management to discover areas of efficient costs and sound pricing decisions for many products, leading to clients satisfaction, more profit margin, more market penetration, and competitive advantages (MdZin et al., 2013, p. 24; Kaplan \& Norton, 1992, p. 57).

7- Cost of Used Resources: Analyzing resources and using them effectively and efficiently reflected in resources absorbed by different activities within corporations, and thus costs can be linked efficiently with targeted outputs and identifying unused capacity (Cooper and Kaplan, 1992; Lin, W., C., 2012, p. 13).

8-Cost of Unused Capacity: it is referred to the cost of resources supplied minus the cost of resources used for each activity in corporations, so managers can use the $\mathrm{ABC}$ to identify unused capacity of resources to create relevant work procedures to overcome inflated costs (Gill, \& Obradovich, 2012, p. 12).

9- Cost Reduction: applying modern tools for costing and try to achieve integral between them to achieve performance efficiency and to improve measures and decision-making processes (Hilton, 2008, p. 231; King,, 2001, p 28). 


\section{Results of the Study}

The Cronbach-Alpha test measures the stability and consistency of the questionnaire elements on the effect of the application of the $\mathrm{ABC}$ system on managing resources and the efficiency of performance for 20 Jordanian manufacturing corporations listed in the ASE. It was found that the Cronbach-Alpha percentage reached more than 92\%, which means that all questions in the questionnaire are consistent as illustrated in Schedule 2.

Schedule 2. Results of the Cronbach-Alpha test for the questions in questionnaire

\begin{tabular}{lcc}
\hline Variables & Questionnaire questions & Cronbach-Alpha \\
\hline All questions & $1-30$ & $92.6 \%$ \\
Appling of ABC & $1-12$ & $89 \%$ \\
Resources cost & $13-19$ & $82 \%$ \\
Unused capacity cost & $20-24$ & $77 \%$ \\
Decrease Product cost & $25-28$ & $81 \%$ \\
Participation from management & $29-30$ & $71 \%$ \\
\hline
\end{tabular}

Further, the Pearson coefficients among elements of the independent variable was used as shown in Schedule 3. The coefficient $(\beta)$ is less than 5 , which means that the three independents variable doesn't have conformity between them self.

Schedule 3. ( $\beta$ ) coefficients between independent variables

\begin{tabular}{lc}
\hline variables & VIF \\
\hline Activity Chart & 1.023 \\
Cost Drivers & 1.027 \\
Value Chains & 1.067
\end{tabular}

\subsection{Results for the First Hypothesis $\mathrm{HO} 1$}

The hypothesis told that there is no effect of applying the ABC on managing resources of Jordanian manufacturing corporation, as illustrate in Schedule 4.

Schedule 4. The Result for Regression on Applying ABC on Managing Used Resources

\begin{tabular}{lllll}
\hline Sig. (2-tailed) & DF & H/L Diff. $\%$ & T & H0 1 \\
\hline .000 & 72 & $45-90 \%$ & 25.614 & Reject
\end{tabular}

As shows on results of Schedule 4, the application of $\mathrm{ABC}$ were benefit, some of which were perceived in manufacturing corporations, as follows: (i) ABC information enabled top management to know the picture of performance and see the competitive strategy of the corporation; (ii) $\mathrm{ABC}$ were able to differentiate between high and low volume products reaching accurate assignments of factory overheads among activities that are consumed resources and then reflecting on accurate cost of products; (iii) $\mathrm{ABC}$ helped the process of cooperation and integration among measurable financial and nonfinancial performance indicators; (iv) improving pricing decisions different products; (v) $\mathrm{ABC}$ can identify duties and responsibilities for every individual within the company at all management levels in manufacturing corporations. Accordingly, Schedule 4 indicated that the sample of manufacturing corporations were applying the $\mathrm{ABC}$ differently (between $45 \%-90 \%$ ) and the results of Schedule 4, pointed to reject the hypothesis, which means that applying $\mathrm{ABC}$ affect on managing used resources in Jordanian manufacturing corporations (sig. = 0.000). This result is consistent with Rozotocki, 2010, p. 7 study.

\subsubsection{Results of Sub Hypothesis HO 1-1}

The hypothesis told that there is no effect of applying the $\mathrm{ABC}$ on identifying cost of resources used in Jordanian manufacturing corporations, as illustrate in Schedule 5.

Schedule 5. The result of regression analysis on Applying ABC on Identifying Cost of Used Resources

\begin{tabular}{lllll}
\hline Sig. & DF & H/L diff. \% & T & HO 1-1 \\
\hline .000 & 72 & $43-88 \%$ & 23.790 & Reject \\
\hline
\end{tabular}

The effect of applying $\mathrm{ABC}$ on identifying cost of resources used among activities reflected in planning and the strategy adopted in corporations. The study found that differences in plans and strategies could lead to different levels of application of the ABC. However, there were some difficulties cause of such application in manufacturing 
companies, as an examples: (i) some managers worked in isolation and weak cooperation with others which led to omission of some procedures and steps of the $\mathrm{ABC}$ application; (ii) some top managers perceived other indirect costs as not relevant to pricing decisions and still considered all indirect costs equally important among all activities and products; and (iii) unclear strategy of the corporation and incomplete information led to cost distortion resulted in dysfunctional behaviors of managers and individuals and negligence of using modern performance evaluation measures in manufacturing companies. Accordingly schedule 5, illustrates regression analysis of this hypothesis, the result showed that (sig. $=0.000$ ), thus the HO 1-1 is rejected, which means that applying ABC affect on identifying cost of used resources in Jordanian manufacturing corporations. This result is consistent with study Askarany, Yazdifar, and Askary, 2010, p. 242.

\subsubsection{The Results of Sub Hypothesis HO 1-2}

The hypothesis told that there is no effect of applying the $\mathrm{ABC}$ on identifying cost of unused capacity in Jordanian manufacturing corporations, as illustrate in Schedule 6.

Schedule 6. The result of regression analysis on Applying ABC on Identifying Cost of Unused Capacity

\begin{tabular}{lllll}
\hline Sig. & DF & H/L diff. \% & T & HO 1-2 \\
\hline .000 & 72 & $40-92 \%$ & 18.107 & Rejectd \\
\hline
\end{tabular}

There was an indirect way of identifying unused capacity in the sample studied based the following formula introduced by Cooper and Kaplan, 1992:

Resources Supplied Cost $=$ Resources Used Cost + Unused Capacity Cost

To achieve that, integration differences found between the $\mathrm{ABC}$ and the $\mathrm{ABM}$ and in particular for those activities that have both quantitative and qualitative cost drivers. Further, informal reports were competing with formal reports where routine reports had low effects on discovering unused capacity. However, many corporations in general can get benefit from the content of informal reports to modify formal reports and embodied such performance information into the framework of the ABC. Accordingly, Schedule 6 illustrates regression analysis of this hypothesis, the result showed that (sig. $=0.000$ ), thus the $\mathrm{HO} 1-2$ is rejected, which means that applying $\mathrm{ABC}$ affect on identifying costs of unused capacity in Jordanian manufacturing corporations. This result is consistent with study Askarany, Yazdifar, and Askary, 2010, p. 244).

\subsection{The Results of Second Hypothesis HO 2}

The hypothesis told that there is no effect of applying the $\mathrm{ABC}$ on performance efficiency in Jordanian manufacturing corporations, as illustrate in Schedule 7.

Schedule 7. The result of regression analysis on Applying ABC on performance efficiency

\begin{tabular}{lllll}
\hline Sig. & DF & H/L diff. \% & T & HO 2 \\
\hline .000 & 72 & $37-95 \%$ & 19.403 & Reject
\end{tabular}

Not all corporations applied ABC equally ending up with different levels of performance efficiency between various activities. This is due to difficulties in differentiating between value added and non- value added activities, such as the cash activity; the creditors activity; the customers activity, that are considered as elements of the value chain; the internal control activity; and the assets management activity. Areas of cost reduction found mostly in defects and wastage of raw materials, maintenance of reliable suppliers, maintenance of permanent supervisors, and facing key competitors were all considered important phases in the value chain in the sample studied. Accordingly, Schedule 7 illustrates regression analysis of this hypothesis, the result showed that (sig. $=0.000$ ), thus the HO 2 is rejected, which means that applying $\mathrm{ABC}$ affect on improving performance efficiency in Jordanian manufacturing corporations. This result is consistent with prior studies by Lin, 2012, p. 14; and Cagwin and Bouwman, 2002, p. 22.

\subsubsection{The Results of Sub Hypothesis HO 2-1}

The hypothesis told that there is no effect of applying the $\mathrm{ABC}$ on reducing cost of products in Jordanian manufacturing corporations, as illustrate in Schedule 8.

Schedule 8 . The result of regression analysis on Applying ABC on performance efficiency

\begin{tabular}{lllll}
\hline Sig. & DF & H/L diff. \% & T & HO 2-1 \\
\hline .000 & 72 & $35-89 \%$ & 17.110 & Reject \\
\hline
\end{tabular}

In order to reduce costs in corporations management should be trained in achieving integration between modern cost 
tools such as the application of $\mathrm{ABC}$ and the $\mathrm{ABM}$, otherwise dysfunctional behaviors could be easily emerged. Adopting accounting methods and control procedures, applied for example on raw materials supply, in activities such as the purchasing, production and cost accounting activities led to mismatching in levels of cooperation between members of the value chain (VC) and reflected in inflated costs. Accordingly, Schedule 8 illustrates regression analysis of this hypothesis, the result showed that (sig. $=0.000$ ), thus the HO 2-1 is rejected, which means that applying ABC affect on cost reduction in Jordanian manufacturing corporations. This result is consistent with prior study (Khan, 2011), (Camacho and Rocha 2008) and Stapleton, Pati, Beach, and Julmanichoti, 2004p. 591.

\subsection{The results of Third Hypothesis HO 3}

The hypothesis told that there is no significant effect of applying the $\mathrm{ABC}$ on managing resources and efficiency of performance in Jordanian manufacturing corporations, as illustrate in Schedule 9.

Schedule 9. The result of regression analysis on Applying ABC on Resources and Performance Efficiency

\begin{tabular}{lllll}
\hline Sig. & DF & H/L diff. \% & T & HO 3 \\
\hline .000 & 72 & $50-100 \%$ & 35.164 & Reject \\
\hline
\end{tabular}

The questionnaire answers emphasized that training programs iv important and there is needing to adopt it for managing resources and upgraded levels of employees at work which helped in achieving loyalty and stability at work in activities with the aim of achieving efficiency of performance at all activities in level in companies. For example, unexpected absence of a key production supervisor was solved by doing the same task by an assistant person, who finished recently a training program. Moreover, modernizing performance measures within the framework of $\mathrm{ABC}$ participation (such as driven activity based costing DABC) can be achieved through experienced individuals who can participate in decision-making processes and able to translate predetermined objectives into actual profits. Results of the one-way ANOVA test, shown in Schedule 9, rejected HO-3 in which means there were an effect of applying ABC on managing resources and performance efficiency in Jordanian manufacturing corporations attributed to management participation $(\mathrm{T}=35.164$ and sig. $=0.000)$. This result is consistent with study Gorzen-Mitka, and Okreglicka, 2014, p.5).

\section{The Study Conclusions and Recommendations}

\subsection{The Study Conclusions}

Reverse to study results, there are some conclusions that identified the effect of applying the ABC system in Jordanian manufacturing corporations:

1. The result of the study showed that the application of $\mathrm{ABC}$ as between moderate to high levels (between $45 \%$ - $90 \%$ ) and the extent of applying $\mathrm{ABC}$ is $72.2 \%$ with the conclusion that the applying $\mathrm{ABC}$ are differences between the companies.

2. There were significant effects of applying $A B C$ on managing resources used in Jordanian manufacturing corporations. The conclusion is that the $\mathrm{ABC}$ were able to differentiate between high and low volume products reaching accurate assignments of factory overheads among activities.

3. There were significant effects of applying ABC on costs of used resources in Jordanian manufacturing corporations. The result referred to differences in the plans and strategies leading to different levels of application of the ABC. Moreover, the main difficulties were in differentiating between added and non-added value activities, unclear strategies, and incomplete information for decision making processes,

4. There were significant effects of applying $\mathrm{ABC}$ on costs of unused capacity in Jordanian manufacturing corporations. The result referred to the integration differences and the lack of formal reporting systems between the $\mathrm{ABC}$ and the $\mathrm{ABM}$, where informal reports were competing with formal reports.

5. There were significant effects of applying $\mathrm{ABC}$ on improving performance efficiency and cost reduction in Jordanian manufacturing corporations. The result showed that whatever activity-slack existed more levels of cooperation also existed between members of the value chain (VC) in the Jordanian context.

\subsection{The Study Recommendations}

The study recommendations are:

1. The full applying of $\mathrm{ABC}$ in Jordanian corporations is desired because its effect on pricing decisions, cost reduction and a competitive ability of corporations in different markets.

2. More case studies on $\mathrm{ABC}, \mathrm{ABM}$, other related modern cost tools are required in cost reduction for all companies 
types to increase efficiency of performance.

\section{The study acknowledgments}

The researchers appreciate and thank all persons who provided comments in preparation of this study, specially, participants, the corporations' management from all levels, and the researchers' colleagues from the accounting sciences department at Zarqa University.

\section{References}

Adams, Steven J. Pryor, Leroy J. Keller, Donald E, \& Harston, Mary E. (2010). Management Accounting Information ,South-Western College Publishing, $4^{\text {th }}$ ed. ,p:334, U.S.A.

Al-Halabi, N. (2013). The Role of Management Control and Accounting Systems in Increasing the Efficiency of Activities of Manufacturing Companies, the International Institute for Science. Technology and Education (IISTE), European Journal of Business and Management, 5(13), 147- 158.

Al-Halabi, N. (2013). The Effect of Applying Balanced Scorecards on Increasing the operational Efficiency of Activities in Manufacturing Companies", the International, Institute for Science Technology and Education (IISTE), paper published in the Journal of Innovative Systems Design and Engineering, ISSN (Paper) 2222-1727, 7(7), 2016, 53-63.

Askarany, D., Yazdifar, H., \& Askary, S. (2010). Supply chain management, activity-based costing and organisational factors. International Journal of Production Economics, 127(2), 238-248. https://doi.org/10.1016/j.ijpe.2009.08.004

Brimson. J. (2001). Activity Accounting: An Activity-Based Costing Approach. ,ed 2 ,p.182, New York, John Wiley.

Cagwin, D., \& Bouwman, M., J. (2002). The Association between Activity-Based Costing and Improvement in Financial Performance, Management Accounting Research, 13(1), March 2002, 1-39.

Camacho, R., R., \& Rocha, w. (2008). Target Costing in Hospital Services: A Study from a Strategic Cost Management Focus. Revista Contabilidade and Finanças USP, (47), 19-30. https://doi.org/10.1590/S1519-70772008000200003

Chi, W., Listic, L., \& Perzner, M. (2011). Is Enhanced Audit Quality Associated with Greater Real Earnings Management ? Accounting Horizons, 25(2), 315-335, UAS. https://doi.org/10.2308/acch-10025

Cooper, R., \& Kaplan, R., S. (1992). Activity-Based Systems: Measuring the Costs of Resource Usage. Accounting Horizons, September, 1-13. From :http://www.sciencedirect.com.

Dorgham, T., Al-Halabi, N., Shanikat, M. (2014). The Effect of Management Control Systems Limiting Fraudulent Practices in Manufacturing Companies. the International Institute for Science Technology and Education -in European Journal of Finance and Accounting(IISTE), 5(6), 1-14, U.K.

Drury, Colin. (2006). Management Accounting For Business, 6th.Ed, p:9, Bath, Patrick Bond, UK.

Dutta, S., \& Gigler, F. (2002). The Effect of Earning Forecasts on Earnings Management. Journal of Accounting Research, 40(3). https://doi.org/10.1111/1475-679X.00065

Ellis, N. J. (2003). Activity Based costing in user services of an Academic Library. Library Trends, 51(3), 334-348.

Garrison, R., Noreen, E., Brewer, P. (2006). Management Accounting, $11^{\text {th }}$ Ed., Pearson Publications.

Gill, A., \& Obradovich, J., D. (2012). The Effect of Corporate Management Control and Accounting Systems and Financial Leverage on the Value of American Firms. International Research Journal of Finance and Economics, ISSN 1450-2887, (91), Euro Journal Publishing , Inc. pp: 1-14.

Gleim \& Flesher. (2014). CMA Review: Financial Reporting, Planning, Performance, and Control. Ed 15, pp: 161-163, Florida USA.

Greenwood, Thomas G., \& James M. Reeve. (2002). Activity-Based Cost Management for Continuous Improvement: A Process Design Framework. Journal of Cost Management, Winter, 22-40. [Online] Available: http://www. proquest.com.

Greiner, A., Kohlbeck, M., \& Smith, T. (2013). Do Auditors Perceive Real earnings Management as a Business Risk? Working Paper, Florida, Atlantic University, UAS.

Gorzen-Mitka, I., Okreglicka, M. (2014). Improving Decision Making in Complexity Environment, (Procedia Economics and Finance, Available online at www.sciencedirect.com, p. 5. 
Hilton, R. (2008). Management Accounting-Creating Value in A Dynamic Business environment, McGraw-Hill Publications, PP: 230-232, USA.

Horngren, C. T., Datar, S. M., Foster, G. (2006). Cost Accounting A Managerial Emphasis, 12th. Ed., pp:142-144, Upper Saddle River : New Jersey,Prentice Hall.

Hopwood, A.G. (1977). An Empirical Study of the Role of Accounting in Performance Evaluation. Journal of Accounting Research, 172.

Judeh, Abed Alhakim Mustafa, Muhammad Khalil, Nimer, Khrisatt, Ula. (2011). The Extent of Using Management Accounting Approaches in Jordanian Manufacturing Listed Companies- A Survey Study, Economic and Management Journal, 1(37), 13-37.

Kaplan, R. \& Atkinson, A. (1997). Advanced Management Accounting, Third Edition, Prentice-Hall International Inc.

Khan ,Imran Ahmad. (2011). Target Cost: The Japanese Strategy for Continuous Improvement, VSRD- IJBMR, 1(3), $177-184$

King, A. (2001). The Current Status of Activity Based Costing Management Accounting, 2 Edition, p:-24- 30, Thomson Learning.

Krishnan,N. (2006). An Application of Activity Based Costing in Higher Learning - Institution: A Local Case Study, Contemporary Management Research, Vol.(2) ,No.(2) Pages (16), Perth, Australia . Management Accounting Standard No. 3400, MAS, (2002), Target Cost, The society of Management Accounts of Canada, Canada.

Lin, W., C. (2012). Financial Performance and Customer Service: An Examination Using Activity-Based Costing of 38 International Airlines. Journal of Air Transport Management, 19, 13-15. https://doi.org/10.1016/j.jairtraman.2011.12.002

Moorthy, K., Yacob, P. (2013). Green Accounting: Cost Measures, Open Journal of Accounting, doi:10.4236/ojacct.2013.21002 Published Online January 2013 (http://www.scirp.org/journal/ojacct), pp:1-7. https://doi.org/10.4236/ojacct.2013.21002

Negulescu, O., Doval E. (2014). The quality of decision making process related to organizations effectiveness. (Procedia Economics and Finance). https://doi.org/10.1016/S2212-5671(14)00548-6

Rapp, Marc Steffen. (2010). Information Asymmetries and the Value-Relevance of cash Flow and Accounting Figures- Empirical Analysis and Implications for Managerial Accounting, Center for Enterpreneurial and Financial Studies (CEFS), TUM Business School- Technische Universitat Munchen, April 2, pp: 1-25.

Reynolds, A., \& Van der Poll. (2015). ABC Implementation in the Nelson Mandela Bay Metropole : How Far should manufacturing - organizations go? African Journals19(2), Southern African Business Review, Africa.

Rozotocki, N. (2010). Activity-Based Management for Electronic Commerce: A Structured Implementation Procedure. Journal of Theoretical and Applied Electronic Commerce Research, ISSN 0718-1876 Electronic Version, 5(1), April, pp. 1-10. [Online] Available: http://www.scielo.cl/.

Schinckus, C. (2010). The Importance of Communicative Rationality on Financial Markets. Journal of Economic and social research, 12(2), 119-144.

Shimizu ,K. (2013). Transforming Target Cost at Toyota, Okayama University, Retrieved from http://www.e.okayama-u.ac.jp/ kshimizu/downloads/iir.pdf

Shiozawa, Y. (2006). Economic and Accounting. A comparison Between Philosophical Background of Two Disciplines in View Complexity Theory. Accounting, Auditing \& Accountability Journal, 12(1), 19-51. https://doi.org/10.1108/09513579910259889

Stapleton, D., Pati, S., Beach, E., \& Julmanichoti, P. (2004). Activity-Based Costing for Logistics and Marketing. Business Process Management Journal, 10(5), 584-597. https://doi.org/10.1108/14637150410559243

Steimer , T. (2000). Activity - Based Accounting For Total Quality Management, Accounting, Englewood Cliffs: New Jersey, Prentice Hall, p:40.

Swenson, D. \& Ansari. (2010). Best Practices in Target Costing. Management Accounting, 2(1), 12-15.

Whittington R., \& Delany, P. (2013). Wiley CPA Examination Review: outlines \& Study Guide, 39th edition, John Wiley \& Sons Inc., p. 77. 